\title{
PROLONGING THE LEASE BY PRODUCTION AND DRILLING, DEFAULT CLAUSES AND CAUSES EXCUSING PERFORMANCE*
}

The oil and gas lease presents a host of problems which are of extreme importance to those involved in the oil and gas industry. It is the purpose of this paper to examine a few of the more predominant of these problems. First, there is the problem concerning the prolonging of the lease by production, drilling and other operations. Secondly, there is the problem of default in the performance of the lease obligations. Thirdly, there is the problem of determining what circumstances will give rise to a valid excuse for nonperformance of the terms of the lease.

The subject matter to be covered is extensive and it is not possible to present an exhaustive and detailed analysis in a paper of this nature. However, the main problems will be discussed and specific problems will be referred to. The problems affecting Crown leases will be discussed separately from those affecting freehold leases.

\section{PROLONGING THE LEASE*}

\section{A. By Production of Leased Substances}

The habendum clause of a freehold form until recently in common use in western Canada, provides for a definite primary term and provision for extension of the lease beyond the primary term "so long thereafter as the leased substances or any of them are produced ...".

The obvious purpose of the "thereafter" portion of the habendum clause is to fix the life of the lease beyond the primary term. Such a clause is often silent as to the amount of production required to maintain the lease. The United States courts have generally held that there must be production in paying quantities to maintain a lease regardless of the language of the particular habendum clause. In other words, at the end of the primary term there must be sufficient production to pay the lessee a profit after deducting the cost of operating the well or wells on the leased lands. However, it is not necessary that there be sufficient to ensure that the cost of drilling is also recovered by the lessee. Nevertheless Summers ${ }^{2}$ cites cases where the general rule has not been followed by some courts and leases have been maintained even though produced at a loss by a lessee.

The Kanstrup ${ }^{2}$ and Kininmonth ${ }^{3}$ cases establish that production for sale or use within the primary term is a condition precedent to the extension of the lease beyond the primary term. However, Canadian courts have not as yet decided the amount of production required to satisfy a "thereafter" clause that is silent as to quantity of production, nor

- This paper was prepared through the combined efforts of J. R. Dunnet. British American Oil Co. Ltd.; J. P. Floyd, McLaws, McLaws \& Co., Calgary; D. C. Hetland, The Atlantic Refining Co.; J. M. Johnson, Chambers, Saucier \& Co., Calgary; J. L. Lebel and R. R. Mahaffey, Chevron Standard Limited; W. B. MacInness, Lougheed, Ballam \& Co., Calgary; and H. D. Wyman, Chambers, Saucier \& Co., Calgary.

- This part of the paper was written by D. C. Hetland.

1 Summers, Oil and Gas, Vol. 2. 300.

2 Canadian Superior Oil of California v. Kanstrup and Scurry-Rainbow Oil Ltd. (1964), 49 W.W.R. 257.

s Canada-Cities Service Petroleum Corporation v. Kininmonth et al (1964), 47 W.W.R. 437. 
have they decided whether continuous and uninterrupted production is necessary to satisfy the requirements in such a clause.

A strict literal interpretation of the words "are produced" would require a lessee to produce continuously and without interruption. Any cessation of production, even temporary, would therefore result in termination of the lease. However, a liberal interpretation of such words may permit temporary cessation of the production if there is a justifiable cause for such temporary cessation.

Mr. George W. Hazlett ${ }^{4}$ points out that in those American States where courts favour a liberal interpretation of the "thereafter" clause, two theories are advanced to support the conclusion that a reasonable cessation of production does not terminate the lease. According to one theory, the discovery of oil and gas in paying quantities vests in the lessee an estate of which he may be deprived only through forfeiture or abandonment. The other theory is that the intent of the "thereafter" clause is to be determined by construing the language of the lease in the light of the purpose of the transaction as indicated by the lease as a whole and not by considering the words of the "thereafter" clause alone. Since occasional interruptions in production are inevitable it is reasonable to assume that the parties to the lease were aware of this possibility and that a literal interpretation would violate the spirit of the contract.

An example of a liberal interpretation appears in the Oklahoma case of Cotner v. Warren ${ }^{5}$ where it was held that a cessation for a period of almost six months was not considered unreasonable and the lease remained in force even though the reason for the cessation was a dispute between the co-lessees. In Canada there is precedent for a liberal interpretation of the habendum clause in the case of Stevenson v. Westgate ${ }^{6}$ decided by the Ontario Court of Appeal. In that case Robertson, C.J.O., states:

... the question whether respondent's rights . . . continued beyond the expiration of one (1) year depends on the proper effect to be given to the words "for as much longer period as oil and gas is found thereon in paying quantities". While appellants are entitled to have a construction placed upon these words that will assure them of continuous operation on their land, so that they may be assured of a reasonable return, so long as respondents continued to occupy it, at the same time, this is a business arrangement, and regard must be had to the reasonable requirements of the business. It is not the fair meaning of the agreement that without interruption respondents must produce a constant flow of oil in paying quantities or lose their right to continue operating. Operations may be interrupted from causes not chargeable to respondents. There may be times in the course of the operations when it cannot be said they are paying. In my opinion, the more liberal interpretation must be placed upon the terms of the agreement than to say, "if there is any such occasion the lease terminates".

The Stevenson case however may not be consistent with the strict and literal interpretation of the habendum clause apparently preferred by the Supreme Court of Canada in recent decisions. Furthermore, it should be noted that in the Stevenson case the "thereafter" clause did not specifically require actual production to maintain the lease. Because occasional interruptions in production are inevitable most modern leases modify the habendum clause by specifically providing for cessation of production. A force majeure clause is commonly inserted, an example of which is as follows:

4 Tenth Annual Institute on Oll and Gas Law and Taxation, Southwestern Legal Foundation, 201.

5 O. \& G.R. 707.

6 (1942) D.L.R. 369. 
provided that if drilling, working or production operations are interrupted or suspended as the result of any cause whatsoever beyond the Lessee's control, the time of such interruption or suspension shall not be counted against the Lessee, anything hereinbefore contained or implied to the contrary notwithstanding.

Since the force majeure clause deals with the interruption of production for reasons beyond control of the lessee it may be argued that interruption of production for any cause within the control of the lessee would terminate the lease. The following situation is an example of where the lease could possibly be terminated in this way. In Alberta, oil wells must be produced according to prescribed monthly production allowables. Consequently, should a lessee produce the full allowable for a well in a period less than a month the well could not be produced for the remainder of the month. Although it is usually possible for a lessee to regulate the flow of production so that his well can produce for the whole month, this may not be desirable because of the tendency of some wells to develop waxing problems when produced at a reduced rate. Nevertheless, it would appear to be hazardous for a lessee to completely discontinue production even for a short time if the cause of discontinuance is within his control. A lessee would run the risk of losing his lease if through negligence or by design he over-produced and had production suspended by the order of conservation authorities.

The shut-in payment clause is another clause commonly interested in freehold leases to modify the requirement of the habendum clause requirement of actual production to maintain the lease at the end of the primary term. An example of such a clause relating to the leased lands only is as follows:

Provided no royalties are otherwise paid hereunder, the Lessee shall pay to the Lessor each year as royalty the sum of Fifty Dollars $(\$ 50.00)$ or the annual acreage rental (whichever is the greater) for all wells on the said lands where gas only or primarily is found and the same is not used or sold, and while the said royalty is so paid each such well shall be deemed to be a producing well hereunder.

An example of such a clause relating to the leased lands as well as pooled lands is as follows:

If all wells on the said lands or the pooled lands are shut in, suspended or otherwise not produced during any year ending on an anniversary date before or after the expiration of the primary term as the result of a lack of or an intermittent market, or any cause whatsoever beyond the Lessee's reasonable control, the Lessee shall pay to the Lessor at the expiration of each said year a sum equal to the delay rental hereinbefore set forth, and each such well shall be deemed to be a producing well hereunder and producing leased substances from the said lands on the said anniversary date.

If a lessee discovers gas the gas well must be capped or shut-in until a market is available. Even if a market for gas exists extensive gathering and processing facilities will be required, the construction of which may involve considerable time and a large capital investment. Consequently, to prevent termination of his lease at the end of the primary term, if there is no actual production for sale or use, the lessee must rely on the shut-in payment clause to maintain the lease.

Although shut-in payments have been involved in some of the recent Canadian cases, the only direction we have as to such payments appears in the Kanstrup ${ }^{7}$ case where it was held that a shut-in royalty payment in the absence of actual production at the end of the primary term must be made prior to the expiration of the primary term in order to maintain the

7 (1964), 49 W.W.R. 257. 
lease. The shut-in payment clause in the Kanstrup lease permitted, but did not obligate, the lessee to make shut-in royalty payments. Nevertheless it can be argued that, whether permissive or obligatory, advance payment of the shut-in royalty must be made in order to deem a shut-in well to be producing.

The shut-in payment clause quoted in the first example above does not provide for the time when payments are to be made. Therefore, a critical problem to be faced by the lessee under such a clause is to decide when payments can be made to achieve the desired effect. The Twelfth Annual Institute $^{8}$ contains an article by $\mathrm{Mr}$. James Noel in which he suggests that the first payment should be made during the period between discovery of gas and the date of shutting-in of the well. He also suggests that out of an abundance of caution the lessee should consider the date of payment as furnishing the anniversary date for subsequent payments. Since nonpayment or improper payment of shut-in payments may trigger the habendum clause and terminate the lease, extreme care must be taken by the lessee in making such payments. It is preferable to err on the side of overpayment rather than to risk termination of the lease.

\section{B. By Drilling Operations Within Primary Term or After Production Ceases* \\ (i) Usual terms in Freehold leases. \\ The typical terms in a freehold lease are as follows:}

To have and enjoy the same for the term of Ten (10) years from the date hereof and so long thereafter as the leased substances or any of them are produced from the said lands, subject to the sooner termination of the said term as hereinafter provided.

Provided that if operations for the drilling of a well are not commenced on the said lands within One (1) year from the date hereof, this lease shall thereupon terminate and be at an end, unless the lessee shall have paid or tendered to the lessor the sum of ....................................................... Dollars, (hereinafter called 'annual acreage rental'), which payment shall confer the privilege of deferring the commencement of drilling operations for a period of One (1) year, and that, in like manner and upon like payments or tenders, the commencement of drilling operations shall be further deferred for like periods successively.

Provided further that if at any time during the said Ten (10) year term and prior to the discovery of production on the said lands, the lessee shall drill a dry well or wells thereon, or if at any time during such term and after the discovery of production on the said lands such production shall cease, then this lease shall terminate at the next ensuing anniversary date hereof unless operations for the drilling of a further well on the said lands shall have been commenced or unless the lessee shall have paid or tendered the annual acreage rental, in which latter event the immediately preceeding proviso hereof governing the payment of the annual acreage rental and effect thereof, shall be deemed to have continued in force.

(ii) Commencement of drilling in lieu of delay rental payment in Freehold leases.

From a review of the authorities it appears that the Canadian and American courts have given a liberal interpretation to the phrase "commence drilling operations". The general rule seems to be that there may be a commencement without actual drilling where operations are begun within the proper time if such operations are conducted diligently and actual drilling commenced without delay. The lessee must act bona fide in beginning and continuing his operations in order to keep the lease in

- This portion of the paper was written by J. R. Dunnet.

8 Twelfth Annual Institute on Oil and Gas Law and Taxation, Southwestern Legal Foundation, 171 . 
good standing. The general rule, which was quoted in the cases of Risvold v. Scott ${ }^{\circ}$ and Wetter v. New Pacalta Oils Ltd. ${ }^{10}$ is set forth in Summers ${ }^{11}$ as follows:

The general rule seems to be that actual drilling is unnecessary, but that the location of wells, hauling lumber on the premises, erection of derricks, providing a water supply, moving machinery on the premises and similar acts preliminary to the beginning of the actual work of drilling, when performed with the bona fide intention to proceed thereafter with diligence toward the completion of the well, constitute a commencement or beginning of a well or drilling operations within the meaing of this clause of the lease.

\section{Summers then goes on to state:}

If the lessee has performed such preliminary acts within the time limited, and has thereafter actually proceeded with the drilling to completion of a well, the intent with which he did the preliminary acts are unquestionable, and the court may rule as a matter of law that the well was commenced within the time specified by the lease. On the other hand, where the lessee has taken such preliminary steps within the time limited, but is prevented from continuing the drilling operations by the lessor, then the intent with which these preliminary acts were done become material. Where the lessee's good faith in the performance of acts preliminary to the commencement of actual drilling is established by uncontroverted evidence of actual completion of the well with due diligence, or the pleadings of the lessee allege that the preliminary acts were done with the bona fide intent of drilling the well with due diligence, the court may rule as a matter of law that these acts were sufficient to constitute a beginning of operations.

But if there is doubt or controversy as to the intent of the lessee in performing the acts claimed as a commencement of operations, then the question should be submitted to the jury.

A provision of a lease requiring the commencement of a well on or before a certain date may be satisfied by the deepening or reconditioning of an abandoned well on the leased premises.

A review of the above two cases and other relevant Canadian cases appears in Lewis and Thompson ${ }^{12}$ as follows:

In Risvold v. Scott a covenant to commence drilling operations within a specified time was held to have been performed by the lessee in procuring a surface lease, digging and cribbing a cellar complete with a runway for the erection of a derrick, making contracts for the erection of a derrick, placing some of the equipment on the ground and arranging a drilling contract, with the bona fide intention to proceed diligently at all times, notwithstanding that the well had not been spudded in. On the other hand, in Wetter v. New Pacalta Oils Ltd., it was held that a lessee had not complied with a clause providing for the commencement of drilling operations within a specified time where his only operations before the expiration of the time was the surveying of the drill site and the operation of a bulldozer over the land, followed by the drilling of a 300 foot hole by a service rig during the first week after the expiration of the time, it being clear that the work was done merely as a pretence to continue the lease; and in Oil City Petroleums (Leduc) Ltd. v. American Leduc Petroleums Ltd. (1952) 3 D.L.R. 577, the Court, while not doubting the good faith of the plaintiffs in the action, held that they had not performed their obligation to commence drilling operations by mere preparatory work consisting of the preparation of the surface and the sinking of a 30 inch hole about three hundred feet deep with a short piece of casing in it, and a water tank nearby, no drilling contract having been let. An early Ontario case, Lang v. Provincial Gas and Fuel Co. (1908) 17 O. L. R. 262, is directly opposed to the rule stated in Summers' Oil and Gas. In that case it was held that the placing of a derrick, an engine, a belt-house and driving pipe at a well site at an expense of $\$ 200$ did not amount to the commencement of a well within six months under penalty of forfeiture. The Court applied the analogy of building contracts and took the view that a breaking of the ground or spuddingin was essential to the commencement of a well. Probably, there is no substantial distinction between the terms 'commence operations' and 'commence drilling operations' under a provision in a lease for commencing work within a specified time, Wulff v. Lundy (1940) 1 WWR 444, (1940) 2 D.L.R. 126. 
Brown gives the following brief review of the American cases on the subject: ${ }^{18}$

In Cromwell v. Lewis, 98 Okla 53, 223 Pac 671 (1923), the Supreme Court of Oklahoma held that the moving of timbers for the derrick upon the ground, and digging the cellar, were sufficient as a commencement.

In Smith v. Gypsy Oil Co., 130 Okla 135, 265 Pac 647 (1928) ,the Oklahoma Supreme Court held that erecting a derrick, moving machinery on the ground, and completing a water well on the premises for the drilling operations were sufficient as a commencement under the rental clause.

The same rule was pronounced in the Oklahoma cases of Aldridge v. Gypsy Oil Co., 132 Okla 13, 268 Pac 1109 (1928) and in Cosden v. Carter Wolf Drilling Co., 183 F2d 761 (10th Cir 1950). But in the case of Gillespie v. Dougherty, 179 Okla 330, 65 P2d 486 (1937), it was held that where the lessee moved some material on the land, dug a slush pit and a water well which had gone dry, he was nevertheless in default as to commencing a well because he was not in good faith, was not financially able to drill, had permitted labor liens to be field against the lease, had given checks therefor which were worthless. The 'commencement' rule was recognized but the case went off on the application of equitable principles.

In Texas the rule seems to be similar to that of Oklahoma. In the case of $\mathrm{Mc}$ Callister v. Texas Company, 223 SW 859 (Tex Civ App 1920), it was held that where the lessee had selected the location of an oil well, hauled derrick timbers to the site and provided a water supply for drilling purposes, there was a "beginning of operations for the drilling of a well ...'

In Terry v. Texas Co., 228 SW 1019 (Tex Civ App 1921), it was held that where the lessee placed timbers for the erection of derrick and machinery, including boiler, on the ground where the oil well was to be drilled, he had complied with the provision requiring him to 'commence to drill' a well within a certain period. The court further held that the word 'commence' is defined as 'to perform the first act of.'

In Wheelock v. Batte, 225 SW2d 591 (Tex Civ App 1949), the lessee, prior to the anniversity date of the lease, filed notice of intention to drill with the Railroad Commission, made an agreement with a drilling contractor to drill a well, employed a surveyor who made a location, and the driller actually commenced operations on the last day for the commencement of the well but ceased operations a day later when the lessor stated that operations had commneced too late. It was held that the unless lease had not terminated.

But in Dunbar v. Fuller, 253 SW2d 684 (Tex Civ App 1952), a late Texas case, it was held that the operator could not be excused for delay in drilling on the ground that it was impossible for him to secure pipe within the time limit set out in the contract, due to regulations of the Petroleum Administrator for War. The court said the appellant was an experienced oil operator and knew of his requirements well in advance of the drilling date and therefore his failure to drill was inexcusable.

In Phillips v. Berg, 120 Kan 446, 243 Pac 1054 (1926), it was held that the hauling of sand and cement to the well location was not a commencement where the actual drilling of the well did not commence until nearly four years later.

In Street v. Masterson, 277 SW 407 (Tex Civ App 1925), it was held that where a lease required the lessee to commence a well within a certain time, but contained no stipulation as to the depth the well should be drilled, the installation of a water drilling rig and drilling a hole twenty feet deep was not a compliance with the drilling clause of the lease. ${ }^{14}$

(iii) Further right to drill to prolong lease after dry hole drilled which had prolonged lease or after production ceases.

If at any time during the primary term and before production the lessee drills a dry hole or holes or if at any time during such term and after production such production ceases, operations for the drilling of a further well must be commenced or delay rental be paid prior to the next ensuing anniversary date of the lease, or it will terminate. The discussion under heading (ii) above with respect to commencement and the date by which drilling must commence to continue the lease apply to the drilling of such a well.

13 Earl A. Brown, The Law of Oil and Gas Leases.

14 For further discussion of these principles see, Williams, Oil and Gas Law, Vol. 3. 
The term of a lease is normally for a primary term and so long thereafter as there is production, and in order that a lease will not terminate after the primary term and after production ceases, provision is usually made for further drilling within ninety days after production ceases. An example of such a proviso to the habendum clause is as follows:

AND FURTHER ALWAYS PROVIDED that if at the end of the said Ten year term the leased substances are not being produced from the said lands or the pooled lands and the Lessee is then engaged in drilling or working operations thereon, or if at any time after the expiration of the said ten year term production of the leased substances has ceased and the Lessee shall have commenced further drilling or working operations within Ninety days after the cessation of said production, then this Lease shall remain in force so long as any drilling or working operations are prosecuted with no cessation of more than Ninety consecutive days, and, if they result in the production of the leased substances or any of them, so long thereafter as the leased substances or any of them are produced from the said lands or the pooled lands; provided that if drilling or working operations are interrupted or suspended as the result of any cause whatsoever beyond the Lessee's reasonable control, or if any well on the said lands or the pooled lands or on any spacing unit of which the said lands or any portion thereof form a part, is shut-in, suspended or otherwise not produced as the result of a lack of or an intermitent market,or any cause whatsoever beyond the Lessee's reasonable control, the time of such interruption or suspension or non-production shall not be counted against the Lessee, anything hereinbefore contained or implied to the contrary notwithstanding.

Again the discussion under heading (ii) above with respect to commencement and the date by which the drilling or working operations must commence to continue the lease apply to such operations, where production ceases beyond the primary term.

\section{By Drimling Operations Commenced Prior to Expiration of . Primary Term and Extending Beyond the Primary Term*}

We turn now to a consideration of Canada-Cities Service Petroleum Corporation v. Kininmonth, ${ }^{1}$ the usual habendum clause in use prior to that case, and, in the light of the Kininmonth case, suggested amendments to avoid the difficulties which such clause presents.

It is obviously illusory to select any particular form of lease as being the standard for the petroleum industry in western Canada. However for the purposes of this paper, and to keep it within reasonable bounds, a form must be selected, and the form in issue in the Kininmonth case is probably as common as any. The relevant portions are set out below with a convenient label attached to each clause for ease of future reference:

To Have and Enjoy the same for the term of 10 years from the date hereof, and so long thereafter as the said substances or any of them are being produced from the said lands, subject to the sonner termination of the said term as hereinafter provided. (Habendum)

Provided that if operations for the drilling of a well are not commenced on the said lands within One (1) year from the date hereof, this lease shall thereupon terminate and be at an end, unless the Lessee shall have paid or tendered to the Lessor the sum of Three hundred twenty $--00 / 100 \ldots(\$ 320.00)$ Dollars, as rental, which payment shall confer the privilege of deferring the commencement of drilling operations for a period of One (1) year, and that, in like manner and upon like payments or tenders, the commencement of drilling operations shall be further deferred for like periods successively; (Drilling Clause)

Provided Further that if at any time during the said 10 year term and prior to the discovery of production on the said lands, the Lessee shall drill a dry well or well thereon, or if at any time during such term and after the discovery of production on the said lands such production shall cease, then this lease shall

- This portion of the paper was written by J. M. Johnson.

1 (1964), 47 W.W.R. 437 (S.C.C.) 
terminate on the next ensuing anniversary date thereof unless further operations for the recovery of the said substances from the said lands shall have been commenced or unless the Lessee shall have paid or tendered the said rental, in which latter event the immediately preceding proviso hereof governing the payments of the said rental and effect thereof, shall be deemed to have continued in force; (Dry hole)

And Further Always Provided that if at any time after the expiration of the said 10 year term the substances are not being produced on the said lands and the Lessee is then engaged in drilling or working operations thereon, this Lease shall remain in force so long as such operations are prosecuted, and if they result in the production of the said substances or any of them, so long thereafter as the said substances or any of them are produced from the said lands, provided that if drilling, working or production operations are interrupted or suspended as the result of any cause whatsoever beyond the Lessee's control, other than the Lessee's lack of funds, the time of such interruption or suspension shall not be counted against the Lessee, anything hereinbefore contained or implied to the contrary notwithstanding. (Development)

A brief discussion of the case itself is warranted. The case concerned a lease, granted May 11th, 1951, with a 10 year primary term and containing the provisions above quoted. On February 27th, 1961 a drilling license to drill a well to the Jumping Pound formation was issued to the lessee. Drilling started shortly thereafter and was completed to the Jumping Pound formation on March 26th, 1961. The Jumping Pound sand was dry but crude oil had been encountered at a lesser depth in the Cardium Sand Formation, and so the lessee applied to the Conservation Board for permission to plug back to the Cardium formation. The application was approved subject to certain conditions, but a road ban in effect from some time in March until May 11th prevented the bringing of fracturing equipment to the well site. Fracturing began May 25th and production was achieved by June 26th, only to have the well shut down ten days later by Conservation Board Order. In summary then, drilling operations commenced prior to the expiration of the primary term but production was not obtained until some time after such expiration.

Turning now to the decisions, the trial decision is unreported and the four majority decisions in the Appellate Division of the Supreme Court of Alberta are of little interest since in finding as a fact that the lease terminated by the long cessation of operations and for reasons which were not beyond the control of the Lessee they do not deal with the question at hand. Thus only the dissenting judgment of Macdonald JA. in the Appellate Division and, of course, the judgment of the Supreme Court of Canada need be considered.

Macdonald J.A. held that the drilling clause allowed the lessee to defer the commencement of drilling operations for a year at a time right up to the end of the primary term, that is, until the last day thereof. Thus in his view the lessee is entitled to commence a well on the last day of the primary term. Relying on American authorities, he held that the right to commence a well during the primary term carries with it, by necessary implication, the right to complete such well after the expiration of the primary term, unless such right is expressly negatived by contract. Macdonald J.A. found strong support for his view in the development clause, which he said clearly contemplated drilling operations being continued after the primary term. In his opinion the lease contained no clauses evidencing a contrary intention. 
The judgment for the five man Supreme Court of Canada was rendered by Martland J. who held:

(i) In accordance with the habendum clause, the lease is extended beyond the 10 year primary term only if at the time of expiration the leased substances, or any of them "are being produced".

(ii) The development clause relates only to the case in which the primary term has already been extended by production which production later ceases. It does not allow drilling operations which are begun prior to the expiration of the primary term to be continued subsequent to expiration until production for the purpose of thus extending the term of the lease.

(iii) The drilling clause does not modify the habendum clause but rather concerns an entirely different matter, the obligation to drill within the lease term. The fact that the lessee has a contractual obligation to drill sometime in the final year of the term does not have the effect of enabling him to defer drilling until nearly the end of the primary term and then to claim an extension of such term, as of right, in which to complete the drilling.

In passing it might be noted that the American jurisprudence on the subject is divided, but the balance of American authorities would appear to adhere to the same view as the Supreme Court of Canada. While the background is very interesting, it is now somewhat academic, for our highest Court has spoken and it is our job as lawyers to adapt ourselves to the situation created thereby. We naturally assume that most people in the petroleum business wish to be able to continue a lease in effect as long as they are in the midst of drilling operations. This is not a matter of laziness or procrastination, for it is possible to imagine situations in which one allows sufficient time to complete and does in fact complete a well within the primary term, only to find it non-productive of petroleum substances but productive of information warranting the drilling of another well on the leased lands. Also one might be in a position similar to that in the Kininmonth case, where petroleum substances in producing quantities are encountered at one formation but the drilling party wishes, having invested so much in the hole already, to continue to test a deeper formation which may be even more productive. If the lessee presses on in this situation, he risks the loss of his lease for not being in production on the expiry date of the primary term; whereas if he does not press on, both the lessor and the lessee might be the losers by reason of a more productive formation not being tested.

Therefore, our object in amending the lease form in issue in the Kininmonth case must be twofold, namely:

(a) to confer on the lessee the right to complete after expiry of the primary term a well, the drilling of which was commenced prior to such expiry, and

(b) the right to commence another well after the expiry of the primary term and within a stated period shortly after the completion and abandonment of the well the drilling of which extended over the expiry date of the primary term.

American jurisprudence on this subject distinguishes between the two situations, (a) and (b) above, and tends to interpret the right to 
continue after the expiry date drilling operations which were commenced before the date as being limited to the well drilled, in the absence of words clearly evidencing a contrary intention. A brief consideration of the American authorities leads to the conclusion that the addition to the habendum clause of the general words "or the said lands are being developed or operated" is sufficient only to allow the completion after the expiry date of a particular well the drilling of which was commenced prior to the expiry date. If that well is a dry hole a new well cannot be commenced. This may be so even though one might be prepared to start the drilling of a new well prior to abandoning the previous well.

The possible variations of amendments to leases are legion and must of course be adapted to the particular lease form in question. For purposes of discussion, the following habendum clause is offered for consideration.

"To Have and Enjoy the same for the term of ten (10) years from the date hereof, so long thereafter as the said substances or any of them are being produced from the said lands (subject to the sooner termination of the said term as hereinafter provided) or so long thereafter as drilling or re-working operations which were commenced during the said term are being continuously prosecuted on the said lands or elsewhere on a drilling or development unit which includes all or part of the said lands; drilling or re-working operations, being deemed to be continuously prosecuted if not more than .......................... days shall elapse between the date of rig release from one well and the date of commencement of drilling or re-working operations on another well; drilling or re-working operations shall be deemed to have been commenced if a drilling rig of reasonably adequate capacity is rigged up on location on the said land or the said drilling or development unit and a drilling bit has penetrated the surface."

If the lease form refers to "commencement" in any way, it is eminently desirable that such term should be defined, as it can obviously be of crucial importance.

\section{DEFAULT CLAUSES AND CAUSES EXCUSING PERFORMANCE*}

\section{A. Default Clause in Leases}

\section{(i) Effect of Default in Performance at Common Law}

Default occurs where a party to a contract fails to perform one or more of the obligations imposed upon him by the contract. For instance, default occurs where a party fails to perform his obligations on the date fixed by the contract for performance; where a party states explicitly that he will not perform his obligation; or where a party does some act which precludes him from performing his obligation.

Default, no matter how it occurs, always entitles the party not in default to conduct an action for damages, but it does not always entitle him to put an end to the contract. The only default that entitles the party not in default to put an end to the contract is a default the effect of which is to make it purposeless for him to proceed with performance. Such a default occurs where a party shows that he no longer intends to be bound

\footnotetext{
- This portion of the paper was prepared by W. B. Macinnes.
} 
by the contract or where there is default in the performance of an obligation that is of major importance to the contract.

Unfortunately, the question of whether or not an obligation is of major importance to the contract is confused by those two words, famous in the law of contract, "condition" and "warranty". These are nebulous words and it is submitted have never been satisfactorily defined for contract purposes. Lord Blackburn said in Heyworth v. Hutchinon: ${ }^{1}$

A clause may be a simple warranty or it may be a condition . . . A condition (goes) to the essence of the contract .... A (warranty) is only collateral to the contract and is the subject of a cross action or matter in reduction of damages.

It is said that breach of a condition normally entitles the party not in default to put an end to the contract; but that breach of a warranty, though it justifies a claim for damages, does not entitle the party not in default to put an end to the contract. This is a distinction as to remedy, but it does not really help us much to decide the basic problem, namely, what term is a "condition" and what term is a "warranty" in a contract. Apparently a "condition" is a major term while a "warranty" is a minor term.

Breach of a minor term in a contract entitles the party not in default to maintain an action for damages against the defaulting party. Default of a major term also entitles him to maintain an action for damages, but in addition he may treat the contract as being at an end and no longer binding upon him. He may also be entitled in certain circumstances to seek recission, but it is not intended here to examine and consider what circumstances are necessary to achieve such a result. The party not in default is not obliged to treat the contract as being at an end upon default of a major term. Instead he may, despite such a breach, hold the defaulting party to his promise in which case the non-defaulting party would also remain liable on the contract but would still be entitled to maintain an action for damages.

\section{(ii) Effect of the Default Clause in an Oil and Gas Lease}

The majority of freehold oil and gas leases in use in western Canada today contain what is commonly called a "Default" clause. There are as many different default clauses in use today as there are different oil and gas leases in use. Notwithstanding such variety a default clause is set out below which seems to be typical of those generally in use today;

In the case of the breach or non-observance or non-performance on the part of the Lessee of any covenant, proviso, condition, restriction or stipulation herein contained which ought to be observed or performed by the Lessee and which has not been waived by the Lessor, the Lessor shall, before bringing any action with respect thereto or declaring any forfeiture, give to the Lessee written notice setting forth the particulars of and requiring it to remedy such default, and in the event that the Lessee shall fail to commence to remedy such default within a period of Ninety (90) days from receipt of such notice, and thereafter diligently proceed to remedy the same, then except as hereinafter provided, this Lease shall thereupon terminate and it shall be lawful for the Lessor into or upon the said lands (or any part thereof in the name of the whole) to re-enter and the same to have again, repossess and enjoy; PROVIDED that this Lease shall not terminate nor be subject to forfeiture or cancellation if there is located on the said lands a well capable of producing the leased substances or any of them, and in that event the Lessor's remedy for any default hereunder shall be for damages only. 
A clause such as this modifies the effect of default at common law by entitling the lessor, if he follows the procedure set forth in the clause, to terminate the lease for default by the lessee in the performance of any one of his obligations and not just those obligations that may be classified as being of major importance to the lease. This right is of course subject to the limitation that the lease shall not terminate if there is located on the leased lands a well capable of producing leased substances, in which event the lessor's remedy for default shall be for damages only.

Also, this clause, which specifically mentions the breach of a condition, modifies the lessor's common law right to put an end to the lease upon default by the lessee in the performance of a condition, because it requires the lessor to give notice of such default to the lessee and to give the lessee an opportuntiy to remedy such default before the lessor can put an end to the lease.

It is stated in Lewis and Thompson" that the default clause "is usually held inapplicable in respect of drilling commitments generally where time is of the essence." The text then goes on to cite Oil City Petroleums (Leduc) v. American Leduc Petroleums Ltd. ${ }^{3}$ However, subject to what is stated below regarding clauses which replace no real obligation on the lessee, it is submitted that if the default clause includes a specific reference to the breach of a condition, that the default clause would apply to a breach of a drilling commitment, and the lessor could not put an end to the lease upon default by the lessee of such a commitment unless the lessor had first followed the procedure stipulated in the default clause.

There are certain clauses in oil and gas leases which place no real obligation on the lessee. For example, the "unless" type lease provides that if operations for the drilling of a well are not commenced on the leased lands within one year from the date of the lease the lease shall terminate and be at an end on the first anniversary date, unless the lessee shall have paid the delay rental to the lessor on or before said anniversary date. This provision places no obligation on the lessee either to drill the well or to pay the delay rental. The following clause is another such example:

Provided further, that if at any time after production of the leased substances or any of them has been obtained such production shall cease this lease shall not be deemed to have terminated if the Lessees within one month after the cessation of production shall have commenced further drilling operations and shall carry them on diligently to completion, and if production of the leased substances or any of them be obtained this lease shall continue further so long as the leased substances or any of them continue to be produced from the said lands;

Under this clause the lessees have the right but not the obligation to continue the lease upon cessation of production, by commencing further drilling. Another example is the permissive shut-in royalty clause which gives the lessee the right but does not impose an obligation upon him to extend the lease beyond the primary term by paying shut-in royalty before the end of the primary term.

The default clause is inapplicable to these "non-obligation" clauses. The lessee has no obligation under these clauses, and therefore, cannot be 
in default with respect to them. It follows that the lessor is not required to give notice to the lessee of default in drilling or paying under an "unless" clause, or in commencing further drilling under a "thereafter" clause, or in paying royalty under a permissive "shut-in royalty" clause. The lease will therefore automatically terminate without any action by the lessor."

The default clause is applicable to the "drill or pay" type of lease which provides that if operations are not commenced on the leased lands within one year of the date of the lease the lessee shall pay to the lessor the annual acreage rental not later than thirty days after expiration of the said one year period. This clearly obligates the lessee to drill or pay and the above quoted default clause requires the lessor to give the lessee notice of default and ninety days to remedy such default before he can reenter or recover damages as the case may be.

There are certain features about default clauses in oil and gas leases which emphasize the inadequacy of the clause from the standpoint of both the lessor and the lessee. From the lessor's standpoint the clause is inadequate because it is doubtful that he will be able to enforce termination without recourse to the courts for a declaration that the lease has terminated. If the lessor does not apply to the court for such a declaration it is very likely that the lessee will apply to the court for relief from forfeiture. From the lessee's standpoint the clause is inadequate because it sets up the lessor as the sole judge of whether or not the lessee is in default. It puts the lessee in the position where up receipt of notice of default from the lessor he can:

(i) remedy the alleged default;

(ii) refuse to remedy the alleged default at the risk of losing the lease; or

(iii) apply to the courts for relief from forfeitures and and a delcaration that he is not in default.

\section{B. Causes Excusing Performance*}

The common law doctrine of frustration or impossibility of performance is a rather recent development. Prior to the 17 th century the law in this area was as follows:

When the law casts a duty upon a man which through no fault of his, he is unable to perform, he is excused for nonperformance; but if he binds himself by contract absolutely to do a thing he cannot escape liability for damages by proof that as events turned out performance is futile or even impossible. ${ }^{1}$

Through further development of the law, particularly in the area of equity, the doctrine of frustration was born. This doctrine is substantiated by two theories. The first of these is the theory of the implied term whereby the court is prepared to infer a term into the contract providing

- This portion of the paper was written by J. P. Floyd.

4 For examples of court decisions regarding these "non-obligation" clauses see the folowing cases:

Unless Clause

East Crest Oil Co. Ltd. v. Strohschein (1952), 4 W.W.R. (N.S.) 553

Chipp v. Hunt (1955), 16 W.W.R. 209

Langlois v. Canadian Superior Oil of California Ltd. (1957), 23 W.W.R. 401

Thereafter Clause-

Krysa v. Opalinski (1960), 32 W.W.R. 346.

Shut-in royalty Clause

Canadian Superior Oil of California Ltd. v. Kanstrup (1963), 39 D.L.R. (2d), 275.

1 Cheshire and Fifoot, Law of Contract (5 ed.), 462. 
that the contract is discharged where a supervening event has caused that contract to be incapable of being performed. The court implies a term into the contract on the basis that it can be presumed that the intention of the parties was that the contract should come to an end in the event of it being incapable of performance. The other theory upon which the doctrine of frustration is based is that the court will impose a just solution where unexpected circumstances having arisen, rendering the contract incapable of performance. The doctrine of frustration or impossibility of performance is therefore really an equitable relief and one which has grown up in relatively recent times.

Upon this doctrine we must superimpose the law affecting the oil and gas industry, particularly with reference to the oil and gas lease. It is a well known fact that in the oil and gas industry the courts will strictly construe most petroleum and natural gas leases against the lessee. Therefor, in result, on the one hand we have the common law doctrine of frustration providing equitable relief to a lessee who is incapable of performing the contract and on the other hand we have the court's practice of strictly construing the lease against the lessee.

The general attitude of the courts in this area is that unless the lessee protects himself adequately by the terms of his lease, then he will be obliged by the terms of his contract to carry out the obligations included therein. It is suggested that this attitude is a throw-back to the state of the common law prior to the 17th century whereby if a man binds himself by contract to carry out certain functions and is unable to do so through intervening events he is still bound and must pay damages as a result of his inability to perform.

The question arises as to what equitable relief can be granted to a lessee under a petroleum and natural gas lease to provide him with the same protection as is afforded to the ordinary contractor by the doctrine of frustration or impossibility of performance. In preparing leases it has been the habit of draftsmen to include a force majeure clause to relieve and discharge the lessee of any liability to perform his obligations when acts beyond his control prevent the performance of these obligations. A force majeure clause can be inserted into the contract to relieve the lessee of the obligations under the delay rental provisions and the drilling commitments under the lease, and, with proper draftsmanship, it is submitted that such a clause can extend the primary term of the lease when drilling obligations are being commenced at the end of the primary term. The authority for this proposition is the Kininmonth case. ${ }^{2}$

As is the normal case, a force majeure clause will be construed against the lessee in the interpretation of a lease, and the cases point out the difficulty of a lessee enforcing this clause in order to gain some relief from his obligations under the lease. Again the Kininmonth ${ }^{8}$ case is a prime example. In this case a road ban prevented the lessee from moving heavy equipment to the well site and the lessee maintained that the primary term was extended by virtue of the force majeure clause. The court took notice of the fact that there was a road ban in existence, but refused to hold that the road ban rendered the force majeure clause operative on the

2 Canada-Cities Service Petroleum Corporation v. Kininmonth (1963), 44 W.W.R. 392 (Alta. C.A.), affirmed by S.C.S. on different grounds, 47 W.W.R. 437.

3 Ibid. 
basis that the lessee could have planned his operations so as to avoid the road ban or possibly could have obtained a certificate permitting him the use of this particular road for moving equipment to his well site. The dissenting Judge in the decision of the Alberta Appellate Division indicated that had the lessee attempted to obtain this permissive certificate and failed in his attempts, the force majeure clause may then have been effective to extend the lease.

Most oil and gas leases used in Canada, until perhaps very recently, have not had a separate force majeure clause. Instead, a proviso to the habendum clause contained force majeure provisions relating to drilling and development. The following is an example of the incorporation of such force majeure provisions:

AND FURTHER ALWAYS PROVIDED that if at the end of the said Ten (10) year term the leased substances are not being produced from the said lands and the Lessee is then engaged in drilling or working operations thereon, or if at any time after the expiration of the said Ten (10) year term production of the leased substances has ceased and the Lessee shall have commenced further drilling or working operations within Ninety (90) days after the cessation of said production, then this Lease shall remain in force so long as any drilling or working operations are prosecuted with no cessation of more than Ninety (90) or any of them, so long thereafter as the leased substances or any of them are produced fromthe said lands; provided that if drilling or working operations are interrupted or suspended as the result of any cause whasoever beyond the Lessee's reasonable control, or if any well on the said lands or on any spacing unit of which the said lands or any portion thereof form a part, is shut-in, suspended or otherwise not produced as the result of a lack of or an intermittent market, or any cause whatsoever beyond the Lessee's reasonable control, the time of such interruption or suspension or non-production shall not be counted against the Lessee, anything hereinbefore contained or implied to the contrary notwithstanding.

Either as the result of a more cautious attitude or because of the Kininmonth case, separate force majeure clauses are now appearing in leases and in some cases are inserted in addition to other force majeure provisions appearing as a part of the proviso to the hadendum clause. An example of an elaborate separate force majeure clause is as follows:

The performance of any of the obligations of the Lessee hereunder shall, notwithstanding anything contained in this Lease to the contrary, be suspended while and so long as the Lessee is prevented from complying with such obligations in part or in whole, by strikes, lockouts, acts of God, accidents, laws, rules and regulations of any governmental bodies or agencies, zoning or land use ordinances of any governmental agency, acts or requests of any governmental officer or agent purporting to act under authority, inability to obtain necessary materials in the open market, or other matters beyond the reasonable control of the Lessee whether similar to the matters herein specifically enumerated or not or while legal action contesting the Lessor's title to said lands or the Lessee's right in said lands by virtue hereof shall be pending final adjudication in a court assuming jurisdiction thereof or while the available market price for oil produced in the field or area in which said lands are located is seventy-five cents (75c) per barrel or less at the well, or when there is no available market for the same at the well. Time consumed in cleaning, repairing, deepening, or improving any producing well or its necessary appurtenances shall not be deemed or construed as an interruption or discontinuance of the Lessee's operations under this Lease. The Lessee need not perform any requirement hereunder, the performance of which would violate any reasonable conservation and/or curtailment program or plan of orderly development to which the Lessee may voluntarily or by order of any governmental agency subscribe or observe.

The above separate force majeure clause relates to the performance of an obligation and as such, it would not relate to drilling or other operations necessary to extend the term of a lease, since such operations are not classed as obligatory in most leases. Therefore, where a force majeure clause is restricted to obligations only, it is desirable to have a force 
majeure provision applicable to the drilling or development provisions in the habendum clause.

It is difficult to give express examples of fact situations in which the force majeure clause has been upheld. Whether or not this clause will be operative is a question of fact and each case must be determined upon its own merits. As a general comment however, it would appear from the Kininmonth case that the lessee must be able to prove complete frustration before he can rely upon the terms of the force majeure clause. He must be able to show that he has done everything within his power to bring about the fulfillment of his obligations under the lease, but due to circumstances which are beyond his control he has been unable to fulfill his obligations.

In conclusion the following is suggested:

1. In order to successfully rely upon a force majeure clause a lessee must do his utmost to fulfill the obligations under the lease and must be frustrated in all such efforts.

2. In order that the force majeure clause shall have the effect desired, the draftsman of the lease must make sure that it extends to all the relevant clauses; it must extend to the habendum clause, it must extend to the delay rental provisions, and it must extend to any other provision by which it is intended to relieve the lessee of some liability which might arise as a result of facts or events which are beyond his reasonable control.

\section{PROBLEMS IN PROLONGING CROWN LEASES}

In preparing this part of the paper an examination of the following types of Crown leases was made:

1. The standard Crown Petroleum and Natural Gas leases for the Provinces of Manitoba, Saskatchewan, Alberta and British Columbia.

2. Indian Lands Oil and Gas Leases.

3. The Oil and Gas Lease under the Canada Oil and Gas Land Regulations.

4. Petroleum Lease and Natural Gas Lease for the Province of Alberta.

In each case there is a primary term specified in either the relevant Act or Regulations. This primary term is for ten years except in the case of the Manitoba Lease which is for three years. The Manitoba Lease also has a secondary term of six years. In all leases excepting the Alberta Petroleum and Natural Gas Lease and the Saskatchewan Petroleum and Natural Gas Lease, the term is renewable for successive fixed periods equal in duration to that of the primary term. Renewability is dependent upon a certain conditions being met, which will be enlarged upon later:

Under the Alberta Petroleum and Natural Gas Lease for each producing well on the lease the primary term is extended as to the spacing units of such producing well and as to land up to a section in size for each such producing well. The term "producing well" is defined in the Act as being one which, in the opinion of the Minister, is capable of production in

\footnotetext{
- This portion of the paper was written by J. L. Lebel and R. R. Mahaffey.
} 
paying quantities. The term "paying quantities" is not defined, although it is understood that with respect to offset obligations, the Government policy is to interpret it as meaning the same as the industry phrase "commercial quantities". This interpretation may or may not be applicable to the amount of production required to extend the lease term. There are other provisions for continuing the lease in force where the lease is subject to reduced rentals by reason of capability of producing gas only or where a well has been commenced before the end of the primary term. Unfortunately, the Act is not too clear as to how long the lease continues under the aforementioned circumstances although it is probably intended that it should continue so long as the well on the lease is a "producing well".

Upon the expiration of the primary term, the Saskatchewan Petroleum and Natural Gas Lease continues if drilling is being conducted continuously and diligently to the satisfaction of the Minister or if there is a producing well or wells on the leased lands. There appears to be no definition of "producing well". The Regulations go on to state that the lease will continue under these circumstances until ninety days after production from the leased lands ceases.

All of the other leases examined are, as stated above, renewable for fixed terms on certain conditions and under certain circumstances. In each case the capacity to renew is conditional upon the existence, in the opinion of the Minister, of a well capable of production of oil or gas. In some cases the reference to production is qualified by the use of phrases such as "commercial quantity" or "paying quantities". In some cases the renewal is subject to such conditions as "the Minister may impose". The one exception to the foregoing is in the case of Manitoba where the renewability of the lease depends upon whether or not the Minister is satisfied that the "productive life" of the lease is longer than the term, and even then it is permissive only, i.e., the Minister is not required to renew the lease. The Minister is also given discretion to grant renewals where there is not production.

As can be seen from the foreging, each of the government jurisdictions attempts to prolong the lease if there is production in certain quantities or the lands are capable of production in those quantities, and in every case phrases such as "in the opinion of the Minister", "to the satisfaction of the Minister", and so on, appear.

In most of the Acts and Regulations governing the lease forms mentioned above there is some sort of provision for grouping of leases for the purposes of carrying out drilling or other exploratory obligations, but none of these have the effect of prolonging the leases beyond the primary term.

In none of the leases is there a so-called "act of God" or "force majeure" clause, but each bristles with default provisions providing for cancellation at the discretion of the Minister in the event of non-payment of rentals, non-payment of royalties or violation of any of the Lessee's covenants. Alberta has an additional provision which automatically terminates the lease if gas, produced in a lease, is used beyond the boundaries of Alberta without the permission of the Lieutenant-Governor-in-Council. 
It would appear that if the Minister purported to cancel a lease for violation of any of the Lessee's covenants, his action would necessarily be based upon the actual existence of such default. Should the default not really exist it would seem that the Lessee could commence an action for a declaratory order providing that there was no default or breach of covenant.

The situation is much more difficult with respect to a failure of the Minister to renew a lease. If a Lessee felt aggrieved by the failure of a Minister to renew a lease what might his remedies be? The answer ostensibly appears to depend upon the category of functions into which the Minister's action or decision falls. These categories are usually said to be:

(a) Ministerial;

(b) Judicial; and

(c) Administrative (discretionary).

Ministerial actions are generally described as those which involve:

(a) no element of discretion; or

(b) the issue of a formal instruction pursuant to a prior determination (which may or may not be judicial) that a certain action be taken in relation to another person or property; or

(c) the carrying out of such an instruction by an inferior officer.

If a Minister's action in refusing to renew a lease were to be categorized by the courts as ministerial it appears that an application for an order in the nature of certiorari would not be available but that there could possibly be an action for mandamus requiring the Minister to renew the lease.

An action or function is generally said to be judicial when it:

(a) results in an order that has conclusive effect; or

(b) when certain procedures are required to be carried out, for instance the requirement of a hearing, or that there be two parties before the trbunal, or where there is an implied duty to give persons who will be directly affected by his decision a prior opportunity to be heard.

A well known statement of the tests of a judicial function is as follows: an authority acts in a judicial capacity when, after investigation and deliberation, it determines an issue conclusively by the application of a pre-existing legal rule or any fixed objective standard to the facts of the situation. ${ }^{3}$ Thus it would appear that if the Minister in making a decision on a renewal of a lease must apply objective standards, his function would undoubtedly be categorized as judicial and would therefore be reviewable.

A function is said to be administrative or descretionary where the tribunal or authority is empowered to exercise its discretion by reference to public policy and is not required to apply fixed principles, or, to put it in another way, where the standards imposed are subjective rather than objective. It must be remembered that the foregoing tests are applied only for the purpose of judicial review and different tests are applied for other purposes, for instance for the purpose of deciding whether or not there is absolute privilege.

The foregoing is a summary of the manner in which the courts decide whether or not the action of a legislative authority will be reviewed. However, one has a distinct feeling that although the courts say

1 de Smith, Judicial Review of Administrative Action, 41. 
that the scope of judicial review is determined by the manner in which the particular function is classified, probably, the truth of the matter is that the classification of functions is determined by the extent to which the courts feel review is desirable and/or practicable. In other words, in many cases the classification results from the courts' own ideas of public policy rather than from the application of any abstract rules. Admittedly, the foregoing statement is not always true, and in many cases the Courts do feel themselves bound by precedent and abstract rules relating to review even though they are inclined otherwise.

As stated above, if the courts categorized the function of the authority as purely ministerial they will not review the action except in an application for an order in the nature of mandamus. However, if the courts decide that the function is purely administrative or discretionary, none of the prerogative writs are available unless there is a clear excess of jurisdiction or failure to exercise jurisdiction or where there is a clear case of bias or personal pecuniary interest.

If the function is classified as judicial, mandamus is not available, but certiorari and prohibition are if there is a lack of jurisdiction or an error of law on the face of the record. The error of law could consist of an inference of fact which is wholly unsupported by the primary facts or one that no reasonable person could draw. Certiorari would also probably be available where there is a clear case of bias, pecuniary interest, fraud or breach of the rules of natural justice.

It is difficult to predict how the courts would proceed where the Minister has refused to renew a lease. The court, considering itself bound by precedent, might class the Minister's function as administrative or discretionary. However, if the court felt sufficiently strongly that injustice had occurred it would probably decide upon a category which would allow review by one of the prerogative writs. In those jurisdictions where no standard of production is set out it would seem that the courts would have less difficulty in deciding whether or not there was production in fact, and if the Minister had decided there was no production, when the plain facts indicated otherwise, the court would undoubtedly review his decision. In those juricdictions where there is a standard of production, such as "commercial quantity", the stiuation is much more difficult, and the court would have much less clear ground upon which to base a decision reviewing the Minister's action.

To the extent that information is available, the Ministers, or their equivalents, in administering petroleum and natural gas leases have always been fair and have been most reluctant not to renew a lease, or to cancel a lease for default unless the facts clearly warranted it. There are apparently no reported cases from western Canada dealing with either a cancellation or a refusal to renew an oil and gas lease. Whether this is because the various Ministers are taking care to be fair or whether no lessee has dared risk the displeasure of the government, one can only surmise. In any event, until some litigation in this area occurs it is extremely difficult, if not foolhardy, to even attempt to make an accurate prediction as to the nature or extent of judicial review. The best one can do is to apply by analogy the existing cases on judicial review relating to other governmental functions. ${ }^{2}$

2 For another anlysis of this problem see, Schmidt, post, p. 359. 